\title{
Tracing Power Relations in Campus Initiations Program
}

\author{
Tabah Maryanah 1,* \\ ${ }^{1}$ Department of Government Sciences, Universitas Lampung, Lampung, Indonesia \\ *Corresponding author. Email: tabah.maryanah@fisip.unila.ac.id
}

\begin{abstract}
The purpose of this paper is to discover what knowledge gives rise to the discourse of the campus initiations program and trace the power relations in it. The study used Michel Foucault's concept about discourse and power. Discourse is produced by a particular knowledge. There are power relations in discourse. Power operates through three mechanisms, namely the hierarchical observation, the judgment of normality, and the examination. Data was collected through focus group discussions, interviews, observations, and documentation. Data were analysed using critical discursive analysis with archaeology of knowledge and genealogy of power from Michel Foucault. The results showed that the campus initiations program emerged because of the knowledge that new students were immature and not yet independent students but entered the foreign world, namely universities. New students need to be given the right information and provisions in order to adapt to their new environment quickly so as to successfully complete their studies. This is what makes it is always held every year. There are power relationship between new students and other academic community. The power operates with the rules made by the organizing committee. New students are under the supervision of the organizing committee and will be punished if they violate the rules or are found guilty by the organizing committee. The violence that occurs in it is part of 'the regime of truth'. The production of violence is a normal practice. Unfortunately, such violence has such a negative effect on new students and institution that violence must to be eliminated.
\end{abstract}

Keywords: "power relations", “discourse”, “disciplinary power”, “campus initiations”

\section{INTRODUCTION}

Violence is one of the important issues in the study of conflict as well as in political science. In conflict studies, when conflict is experiencing high escalation, conflict is often accompanied by violence. Clashes between police and demonstrators, fights between villages, student clashes, bombings, and so on occurred during a high escalation of conflict. Political practices in formal political areas are also often marred by acts of violence. Power struggles, for example, often result in war, assassinations, riots, violence in elections or other acts of violence. Violence also often occurs in the implementation of development programs [1]. (Triono, 1999). In addition to occurring in formal regional politics, violence also occurs in political practices in everyday life. For example, sexual violence, domestic violence, violence in the process of education in formal educational institutions, and so on.

Violence in education in Indonesia is quite high. According to the results of the Program for International Students Assessment (PISA) research in 2018 that $41.1 \%$ of students in Indonesia admitted to having experienced bullying [2]. This figure is very far above the average of member countries of the Organization for Economic Co-operation and Development (OECD) which only reached $22.7 \%$. The high bullying rate makes Indonesia ranks fifth highest out of 78 countries as the country with the most students experiencing bullying. 
Some of the violence on higher education institutions occurs in campus initiations program activities. Records [3] in the space of five years, namely from 2000 to 2015, there were at least 10 cases of violence in campus initiations programs, resulting in death. [4] also noted that there was some heartbreaking violence in the campus initiations program. The form of violence at Surabaya State University (Unesa) that new students was snapped by senior students for not wearing belts in September 2020. Violence at Khairun University, Ternate in August 2019, new students were ordered by senior students to drink water in the glass and spit it out again into the glass. That means students who drink in the second and so on drink water that has been mixed with the saliva of previous students. Violence at Makassar Hasanuddin University (Unhas) that occurred in August 1996, senior students kicked with shoes, slapped, pushed, and cut hair to injure the head of new students.

Violence also occurred at the University of Lampung (Unila) during the basic education of the Student Activities Unit of nature lovers 'Cakrawala' in September 2019 which resulted in a new student dying due to violence by senior students [4]. Violence in the campus initiation program that recently occurred in Sebelas Maret University (UNS). New student who attended the Student Regiment's education and training even died in October 2021 due to violence committed by senior students [5].

So much violence that occurs in the implementation of campus initiations programs and even some of the resulting in new students dying is very concerning. Violence in campus initiations programs is also counterproductive to the purpose of held the campus initiations program itself.

Violence in the process of education in formal institutions has been widely researched from various aspects. Such as sexual harassment [6], gender-based violence [7], gender-based violence and sexual harassment at universities [8], violence against black students (Mustafa, 2017), violence experienced by indegeneous students [9], symbolic violence [10], the relationship between violence and education [11] and efforts to overcome violence in the world of education [12].

Violence in the educational process in formal institutions takes various forms. such as sexual harassment (Fredrik Bondestam and Maja Lundqvist, 2020), gender-based violence (Licia Bosco Damous and Colette Guillop'e, 202), gender-based violence and sexual harassment in universities (Paredes MM, Miño SV, Hernández RS 2021), violence against black students ((Mustafa, 2017), violence experienced by indigenous students (Gordon, et all, 2018), symbolic violence (Murat Ergin, Bruce Rankin \& Fatoş Gökşen, 2018), the relationship between violence and education
(Conrad Hughes1, 2019) and efforts to overcome violence in education (Meredian Alam, 1999).

The above research looks more at violence in college education with a focus on violence. Violence is seen as an empirical act in order to grab the interests of the perpetrator. Violence is not seen as part of a 'regime of truth'. This research will emphasize how power/knowledge relations in the educational process, especially in campus initiations programs, are produced and how power operates. It is at this point that the uniqueness of this article can be found. Based on differences and uniqueness with previous research, the purpose of this article is to analyze how power/knowledge relations and how power operates.

\section{THEORETICAL FRAMEWORK}

Power is strongly related to knowledge and cannot be separated albeit semantically [13]. Human knowledge forms a regime of power through the mechanism of discipline and the imposition of norms of behavior. Knowledge also determines how humans become subjects through the truth produced by discourse. Thus it is discourse that determines the subject, not the other way around, the subject that determines the discourse. Since power cannot be separated from knowledge, it is not something, not control over a set of institutions, or a hidden pattern of history, so the most important thing is to discover how it operates.

To discover how power operates it is necessary to isolate, identify, and analyze the network of relationships that create political technology. Political technology in the context of this power is called disciplinary power (). Disciplinary power develops and operates through three main mechanisms [14], namely:

1. Hierarchical observation, i.e. the ability of those responsible to observe the entire range of their surveillance in one glance.

2. Judgment of normality, namely the ability to determine who is normal and who is not, and to punish those who violate norms. This norm is divided into three dimensions, namely time, activity, and behavior. Norms in the time dimension for example if someone is late. Norms in activity for example if someone does not pay attention. While norms in the behavioral dimension, for example, if someone does not behave properly.

3. Examination, i.e. observation examines people and their assessment according to the norms in the three dimensions above. This mechanism makes use of hierarchical observations and uses knowledge to determine the standard of normality, what is assumed to be true, in all areas of life.

This understanding of the power network can be used to understand the operation of power in social 
institutions at the most routine daily level, such as educational institutions, religious institutions, and correctional institutions.

Power is not limited to political institutions such as the state, bureaucracy, military or political parties. But power has a direct and creative role in social life. Therefore power is productive. Power is productive when disciplined technology creates permanent links to certain institutional frameworks. This productive power is a positive aspect of power.

Power is multi-directional and operates from the top down and from the bottom up. Although power is at its peak when it is in certain institutions such as schools, prisons or hospitals. However, this does not mean that power is a superstructure or quality of an institution.

Power is the general matrix of power relations in a given society at a given time. There is no one outside this matrix, and no one above it. Prisoners and wardens are subject to the same disciplinary and supervisory procedures practiced in prisons, and act within the true confines of prison architecture. Likewise in educational institutions, all academics are subject to the same disciplinary and supervisory procedures.

While all are trapped in a web of power relations, there is also rule and domination: wardens still have certain advantages under prison rules, as do those who are in charge of them and those who design prisons. Thus, domination is not the essence of power. Domination does exist, but power is also applied to the rulers and not only to the ruled. Power is exercised and not held. In other words, it is absolutely not important to measure strength, or try to find it.

The most important question is how power acts and what it produces. Power, among others, produces obedience, discipline, systematic knowledge of prisoners, which in the context of this research is about the campus initiations program for new students.

\section{METHOD}

This research is qualitative research. Data are collected through focus group discussion (FGD), interviews, observations, and docentation. FGD is carried out on new students in the class of 2019. Interviews are conducted on new students, senior students, lecturers, and employees who know or witness campus introduction activities. Observations were made at the time the campus initiations program in 2019 was implemented. For convenience the informant details the research location, college institution, and informant are kept secret. The data was analyzed using critical discursive analysis using archaeological methods of knowledge and genealogy of power from Michael Foucault. Archaeological methods are used to discover how campus initiations programs become accepted truths. Power genealogy methods are used to discover how campus initiations programs are normalized.

For reasons of convenience of the informants, the details of the research location, higher education institutions, and informants are kept secret.

\section{RESULT AND DISCUSSION}

\subsection{Campus initiations program As A Discourse}

This section describes how campus initiations programs are accepted as a truth that we accept or become discourse. Discourse is the system that makes up the way we perceive reality. Discourse is associated with power relations [15]. In other words discourse is a statement that we accept the truth, both we agree and we criticize. One accepts a discourse, although sometimes also criticizing, always in it contained a power relationship.

Campus initiations program is an annual routine activity organized by universities in Indonesia, both public and private universities. This program is carried out nationally based on guidance from the ministry of education. No official documentation has been found since when the program began but it can be ascertained that in the 1970s this program has been implemented. Each college and from year to year, this program has different designations.

This program aims to provide debriefing to new students in order to more quickly adapt to the campus environment. In addition, to prepare new students through the transition process into mature and independent students. Another goal is for new students to successfully pursue education in college. This program is a momentum for new students to get the right information about the education system in universities both academic and non-academic fields [16].

Based on the document of the Director General of Learning and Student Affairs About the General Guidelines for the Introduction of Campus Life for New Students (PKKMB) in 2019 it is known that the campus initiations program was implemented because of the knowledge that new students are still unfamiliar to the new campus. Because new students are still unfamiliar to the new campus is believed to hinder the adaptation process. So that new students can quickly adapt to their new campus, a campus initiations program is held.

The Document of the Director General of Learning and Student Affairs also states that new students are immature and not yet independent human beings. This assumption according to the authors is related to the age of new students who are on average 17 years old, an age that is just about to enter adulthood. New students are considered as human beings who have not been independent related to the education system undertaken while in senior high school. The education system in senior high school still uses the classical system. The classical system makes all students go to education 
together and take the same subject matter. While the education system in college uses a credit system. Credit systems allow a person to complete his or her education faster or later. For students who excel in the academic field will be able to complete their education faster than their friends. Conversely, students who have poor academic achievement will be slow to complete their studies. The differences in the education system in senior high school and in college make campus initiations programs an accepted truth.

In addition to the above knowledge, the knowledge that understanding a person's situation and condition will be able to support the success of studies also affects the campus initiations program to be an accepted truth. Various kinds of knowledge above make the Director General Learning and Student Affairs have confidence that the campus initiations program will support the education process so that new students succeed in studying in college.

Another knowledge that drives campus initiations programs into accepted truth is that the right information will allow one to take appropriate action as well. The right information can also encourage new students to make the right learning plans and strategies. As the name suggests, the campus initiations program provides a variety of information, both academic information and non-academic information at the college concerned. Thus, through the new student campus initiations program will get the right information about the new campus. This knowledge is what prompted The Director General of Learning and Student Affairs to establish that this campus initiations program is a momentum for new students to get the right information about the education system in universities both academic and non-academic fields.

Based on the objectives of the organization, the campus initiations program becomes very strategic for new students and educational institutions. Through this program students get various information about the world of higher education on campus. With this information, new students can recognize the fundamental difference between secondary education that has just been completed and the education in college to be pursued. Based on information from this program, new students can start designing strategies on how to complete their education in college as well as how to live a student role. For institutions, this program can be a momentum to socialize the values embraced and help students plan strategies, activities, and determine the roles that will be chosen by new students.

The brief illustration above shows that the campus initiations program for new students becomes a discourse. As a discourse, the campus initiations program becomes a regime of truth in college. As a truth regime, the campus initiations program is considered important to always be implemented in welcoming new students every year. Higher education campuses in Indonesia, both private and state campuses, organize campus initiations programs every time new students come. New students follow the campus initiations program at their respective colleges.

\subsection{Power Operations in Campus initiations program}

Discourse on campus initiations programs will be understandable if it is associated with power relations. As previously written, power operates through three main mechanisms: observation of hierarchy, judgment of normality, and examination. The campus initiations program gave rise to the classification of organizing committees and participants of the activity. College leaders, lecturers, senior students, and other elements of the academic community become the organizing committee. New students as participants. Campus initiations programs also make students classified into new students and senior students. These classifications form a system or power relationship. Political relations between college leaders and other academic community and new students that cause the leadership of the college and other academic community, as the organizing committee of the campus initiations program, has power over new students.

Power in this context is not coercive, open is also passive. Power comes through normalization. Normalization is disciplining. Normalization makes discourse or knowledge as something normal or something to be done so that the indicated or controlled subject feels not forced to do so. The organizing committee of the campus initiations program is considered normal to know more about the campus. Senior students, who are also the organizing committee, will determine the standard norms in the campus initiations program. Senior students also determine whether a freshman's actions are considered right or wrong. Senior students also determine the punishment if the freshman violates the norm or is considered wrong.

Based on information obtained through norms in the Campus initiations program in 2019 more applicable to new students. In the time dimension, new students must be present on time at each activity. New students must also be on time in collecting tasks given by senior students. In the activity dimension, senior students arrange the clothes that new students must wear and assign assignments to new students. The standard male student dress code on Mondays was white long-sleeved hems, black trousers, black lengths, black belts, and black fantovel shoes. Standar norma berpakaian mahasiswa perempuan pada hari Senin adalah hem lengan panjang berwarna putih, rok panjang dengan model A berwarna hitam, dasi panjang berwarna hitam, ikat pinggang berwarna hitam, serta sepatu fantovel dengan model tertentu berwarna hitam. Mahasiswa perempuan yang mengenakan penutup kepala juga harus berwarna hitam (FGD, 2019). 
The standard dress norms of male students on Wednesdays are batik hem, black trousers, black belts, and black vantofel shoes. The standard dress code of female students on Wednesdays is batik, long skirts with black or dark A models, black belts, and vantofel shoes with certain models in black. Female students wearing head coverings must also be black (FGD, 2019).

Power operations in the dimension of activity are also manifested in the creation of standards for the collection of senior students' signature collection norms. New students are required to collect the signatures of 250 senior students, which then increases to 300 pieces. The activity of collecting such signatures was given a very short time, which is four days. Orders given on Friday, Wednesdays have to be collected. Saturday and Sunday are holidays (FGD, 2019).

Power operations in the behavioral dimension occur through the standard setting of norms of behaving for new students. Male freshmen should shave their hair short, no more than two centimeters. Women should not wear makeup during orientation. New students should respect senior students. For example by greeting or smiling to the senior student firstly (FGD, 2019).

Senior students monitor and supervise new students whether they follow the standard norms set by senior students or not. Freshmen who violate the norm standards will be punished by senior students. Forms of punishment can be punishments of entertaining nature such as singing or reading poetry. But there are often verbal punishments such as swearing and getting angry with loud noises. In addition, physical punishment such as push-ups, up and down stairs by squatting, beatings, ganging, kicking chairs that injure freshmen. Penalties for violations are also in the form of shoes thrown and books collection of senior students' signatures torn (FGD, 2019).

The violence that occurs in campus initiations programs becomes part of the truth regime in campus initiations program discourse. This is reinforced by the response given when there is criticism of violence on the grounds that these things have become traditions and habits in welcoming new students. There is no guilt or remorse for committing violence against new students (Interview, 2019).

Power is a productive arena, which produces something. The mechanism of operation of such power in to discipline against new students. Through various standards of norms, supervision, and examination is expected to emerge a body of new students who are disciplined and compact. Discipline by giving punishment is also a discourse because of the knowledge that punishment in the form of actions and speech is indeed considered a quick way to change a person's behavior [16]. In addition, there is a belief that the punishments can prepare the mentality of new students to accelerate the adaptation of new environments that are still foreign. This means that violence is committed in the framework of that truth.

Violence is already considered as part of the truth also found from the response of senior students, lecturers, and other academic community to the act of violence of senior students against new students. Some senior students who were interviewed stated that the acts of senior student violence in campus initiations programs are common, even the actions of senior students against new students in 2019 are much milder than in previous years. Other students say that it has become a culture in welcoming new students. An employee also stated that what senior students do to new students is a tradition, a habit that has been done over and over again. A lecturer also stated that what happened during the introduction of the campus was trivial and not serious. Many lecturers allow violence to happen repeatedly every year.

But keep in mind that discipline by senior students against new students by using violence has some negative side effects. First, the discipline by senior students against new students has participated in legalizing violence. As with FGD results, interviews, and observations, senior students commit many acts of violence against new students. The violence is in the form of psychic violence, verbal violence, even physical violence. Psychical violence occurred in the form that senior student threats not to be helped new students in taking care of a single tuition appeal (UKT) if not compliant. Another psychical violence is banning female students from wearing makeup. Verbal violence is carried out by senior students in the form of shouts, chants, and expressions of anger in a high tone, especially to new students who violate the rules or are considered wrong. Another form of verbal violence is abusive speech, such as 'pretentious', because wearing makeup and 'just take off hijab anyway photos on social media are also not hijab'. While physical violence committed by senior students is to check the bodies of female participants whether hiding beauty tools, even though it is done by the women's organizing committee. Other forms of physical violence are beatings, ganging, throwing with solid objects, kicking chairs that injure participants, push-up penalties, squatting street punishment from the first floor to the third floor.

Second, the discipline of violence has raised fear for new students against senior students. At the time of FGD, even 2019 students stated that new students were more afraid of senior students compared to lecturers. New students also feel uncomfortable being on campus during the campus introduction period and want to leave campus immediately after the lecture activities are completed. A further implication of fear as one of the results of a campus initiations program is that most students become afraid to express their opinions and 
take certain actions during the course of the course. This will hinder the self-development of new students and their succeed in pursuing education. Another serious effect is that when the following years the freshman has become a senior student will vent resentment to the new students. This will make violence passed down through the generations because it is considered part of the truth.

\section{CONCLUSION}

Campus initiations program is a discourse or a truth that is widely accepted in the world of education. In every discourse there is always a power relation. Discourse about campus initiations programs arises because of the knowledge that new students are immature and not yet independent students but enter foreign universities. Therefore, new students need to be given the right information and provisions in order to adapt to their new environment quickly so as to successfully complete their studies. This is what makes the campus initiations program always held every year, welcoming the arrival of new students. Through this program, new students get a variety of information about higher education on campus.

In campus initiations program power operated through hierarchical observation mechanisms, normality judgment through dimensions of time, activity, and behavior, as well as examination. During the campus initiations program, new students are bound by the rules made by the committee and are under the supervision of the committee. New students will be punished if they break the rules or are found guilty by the organizing committee.

The violence that occurs in campus initiations program is part of the truth regime. Violence in campus initiations program has short-term implications in the form of new students' fear of senior students and feeling uncomfortable on campus. While the long-term effects, can hinder self-development and success in the study of new students as well as endless revenge. This is counter-productive to the purpose of introducing the campus itself. Given the magnitude of the negative impact of violence in campus initiations program, both short-term and long-term, violence needs to be eliminated from campus initiations program.

\section{REFERENCES}

[1] L. Trijono, "Refleksi tentang Kekerasan Pembangunan Menuuju Pembangunan Perspektif Ham," Jurnal Sosial Politik, vol. 2, no. 3, pp. 23-47, Mar. 1999.

[2] D. H. Jayani, "PISA: Murid Korban 'Bully' di Indonesia Tertinggi Kelima di Dunia,” Dec. 12, 2019. https://databoks.katadata.co.id/datapublish/ 2019/12/12/pisa-murid-korban-bully-diindonesia-tertinggi-kelima-di-dunia (accessed Nov. 10, 2021).

[3] MSR, "10 Kasus Kematian Akibat Plonco Ospek Maut,” Aug. 04, 2015. https://edukasi.okezone.com/read/2015/08/ 04/65/1190267/10-kasus-kematian-akibatplonco-ospek-maut (accessed Nov. 10, 2021).

[4] D. B. Bramasta, "Selain di Unesa, Berikut Sederet Kejadian Memilukan Saat Ospek Mahasiswa Baru," Sep. 16, 2020. https://www.kompas.com/tren/read/2020/0 9/16/140525665/selain-di-unesa-berikutsederet-kejadian-memilukan-saat-ospekmahasiswa?page $=$ all (accessed Nov. 10, 2021).

[5] J. A Nashr, "Polisi Sebut Ada Tanda Kekerasan di Tubuh Mahasiswa UNS yang Tewas saat Diklat ," Oct. 26, 2021. https://nasional.tempo.co/read/1521364/pol isi-sebut-ada-tanda-kekerasan-di-tubuhmahasiswa-uns-yang-tewas-saat-diklat (accessed Nov. 10, 2021).

[6] F. Bondestam and M. Lundqvist, "Sexual harassment in higher education - a systematic review," European Journal of Higher Education, vol. 10, no. 4, Oct. 2020, doi: 10.1080/21568235.2020.1729833.

[7] L. Bosco Damous and C. Guillopé, "Gender-based violence in higher education and research: a European perspective," Pure and Applied Chemistry, vol. 93, no. 8, Aug. 2021, doi: 10.1515/pac-2021-0401.

[8] M. Mejía Paredes, S. Veloz Miño, and R. Saeteros Hernández, "Gender Violence in the University: The Role of Higher Education Institutions in its Prevention," ESPOCH Congresses: The Ecuadorian Journal of S.T.E.A.M., Aug. 2021, doi: 10.18502/espoch.v1i1.9586.

[9] R. Gordon, K. J. Conron, J. P Calzo, and S. B. Austin, "Gender Expression, Violence, and Bullying Victimization: Findings From Probability Samples of High School Students in 4 US School Districts," Journal of School Health, vol. 88, no. 4, 2018.

[10] M. Ergin, B. Rankin, and F. Gökşen, "Education and symbolic violence in 
contemporary Turkey," British Journal of Sociology of Education, vol. 40, no. 1, Jan. 2019 , doi:

10.1080/01425692.2018.1500274.

[11] C. Hughes, "Addressing violence in education: From policy to practice," PROSPECTS, vol. 48, no. 1-2, Jan. 2020, doi: 10.1007/s11125-019-09445-1.

[12] M. Alam, "Journey to Zero Violence: An Experience of Youth-Based Civil Society Organization in Eradicating Violent Practices in the School Initiation Programme," Jurnal Ilmu Sosial dan Ilmu Politik, vol. 13, no. 1, pp. 20-30, Jul. 2009.

[13] M. Foucault, Discipline and Punish: The Birth of The Prison. New York: Vintage Books., 1975.

[14] E. Sadan, "Empowerment and Community Planning.," in Empowerment and Community Planning: Theory and Practice of People-Focused Social Solutions., Tel Aviv: Hakibbutz Hameuchad Publishers [in Hebrew]., 1997.

[15] S. Mills, Michael Foucault. New York: Routledge, 2003.

[16] R. Azzahra, "Hindari Kekerasan dan Bullying pada Pengenalan Kampus," Sep. 16, 2020. http://rdk.fidkom.uinjkt.ac.id/index.php/20 20/09/16/hindari-kekerasan-dan-bullyingpada-pengenalan-kampus/ (accessed Nov. 10, 2021). 